\title{
Effects of Formaldehyde and Vimentin Expression in Rat Skin
}

\author{
Efectos del Formaldehído y Expresión de Vimentina en la Piel de Rata
}

Sevgi Kalkanli*; Nevin Kalkanli**; Engin Deveci ${ }^{* * *}$; Tuba Dal ${ }^{* * * *}$ \& Özlem Baran ${ }^{* * * * *}$

KALKANLI, S.; KALKANLI, N.; DEVECI, E.; DAL, T. \& BARAN, O. Effects of formaldehyde and vimentin expression in rat skin. Int. J. Morphol., 31(3):845-848, 2013.

SUMMARY: The Wistar rats ( 9 weeks old, 180-200 g body weight) used in these trials were divided into two groups of 16 animals each (Control group and Experimental group). 100x65x100 in the sizes of the experimental group were taken into a glass vase. During the time period of 8 weeks, 5 days a week with 8 hours the inhalation of $10 \mathrm{ppm}$ formaldehyde was made. Skin was removed and placed in $10 \%$ formaline. Sections were stained with Hematoxylene-Eosine, Trichrome-Masson and observed under light microscope. In this study, histopathological and immunohistochemical techniques due to the impact of the changes in formaldehyde and examined the distribution of vimentin.

KEY WORDS: Formaldehyde; Skin; Vimentin.

\section{INTRODUCTION}

Formaldehyde is an extraordinary resolution of low molecular weight which kept the upper respiratory tract inhalation. Despite some similarities between the two routes, there are also important mechanistic differences in the currently understood etiology of allergic contact dermatitis, the most common skin allergic disease and asthma and allergic rhinitis, the most common respiratory allergies. Formaldehyde is commonly used in the production of various industrial and medical products. Formaldehyde is a chemical which is traditionally used for fixing cadavers and routine histopathology techniques. It is vaporised during the dissection and practical study of a cadaver. Previous studies have shown that this vapor may cause clinical symptoms such as throat, eye, skin and nasal irritation (Golalipour et al., 2007). Exposure to formaldehyde vapors can cause irritation of mucous membranes and allergic sensitization of skin, but the critical target is upper respiratory tract (Mathur \& Rastogi, 2007) Vimentin filaments are more broadly distributed among tissues such as in the cells of the mesenchymal origin, certain other non-epithelial cells of various other tissues (Bavdek et al., 1997; Kacem et al., 1996; Lazarides, 1980; Rode et al., 1998) In this study, histopathological and immunohistochemical techniques due to the impact of the changes in formaldehyde and examined the distribution of vimentin.

\section{MATERIAL AND METHOD}

The Wistar rats ( 9 weeks old, 180-200 g body weight) used in these trials were divided into two groups of 16 animals each (Control group and Experimental group). The rats were obtained from the Department of Medical Science Application and Research centre of Dicle University. All the animals were indivially housed in stainless steel cages at room temparature. The animals had free access to standart laboratory rat pellet and water 100x65x100 in the sizes of the experimental group were taken into a glass vase. During the time period of 8 weeks, 5 days a week with 8 hours the inhalation of $10 \mathrm{ppm}$ formaldehyde was made. Formaldehyde vapor in the environment,with a special air pump ventilation constant volume, pressure and temperature achieved. The face skin were dissected under ketamine hidrochloride anesthesia and placed in $10 \%$ formaldehide solution. They were placed in parafine inclusion melted at $58^{\circ} \mathrm{C}$ after treatment with xylol, the 4-6 $\mu \mathrm{m}$ sections were taken by rotary microtome and the sections were stained with Hematoxylene-Eosin (H-E) and Trichrommasson dyes and then observed under olympus BH2 light microscopy to determine histological changes.

Immunohistochemistry stain. Phosphate-buffered solution (PBS, pH 7.2) were washed $3 \times 5$ minutes. Citrate buffer, tissue sections were antigenically masked for the abolition of the environment and $2 \times 5$ minutes in a microwave oven,

\footnotetext{
Department of Immunology, Dicle University Faculty of Medicine, Diyarbakir, Turkey.

** Department of Dermatology and Venereology, Veni Vidi Hospital, Diyarbakir, Turkey.

**** Department of Histology and Embryology, Dicle University School of Medicine, Diyarbakir, Turkey.

***** Department of Microbiology, Dicle University Faculty of Medicine, Diyarbakir, Turkey.
} 


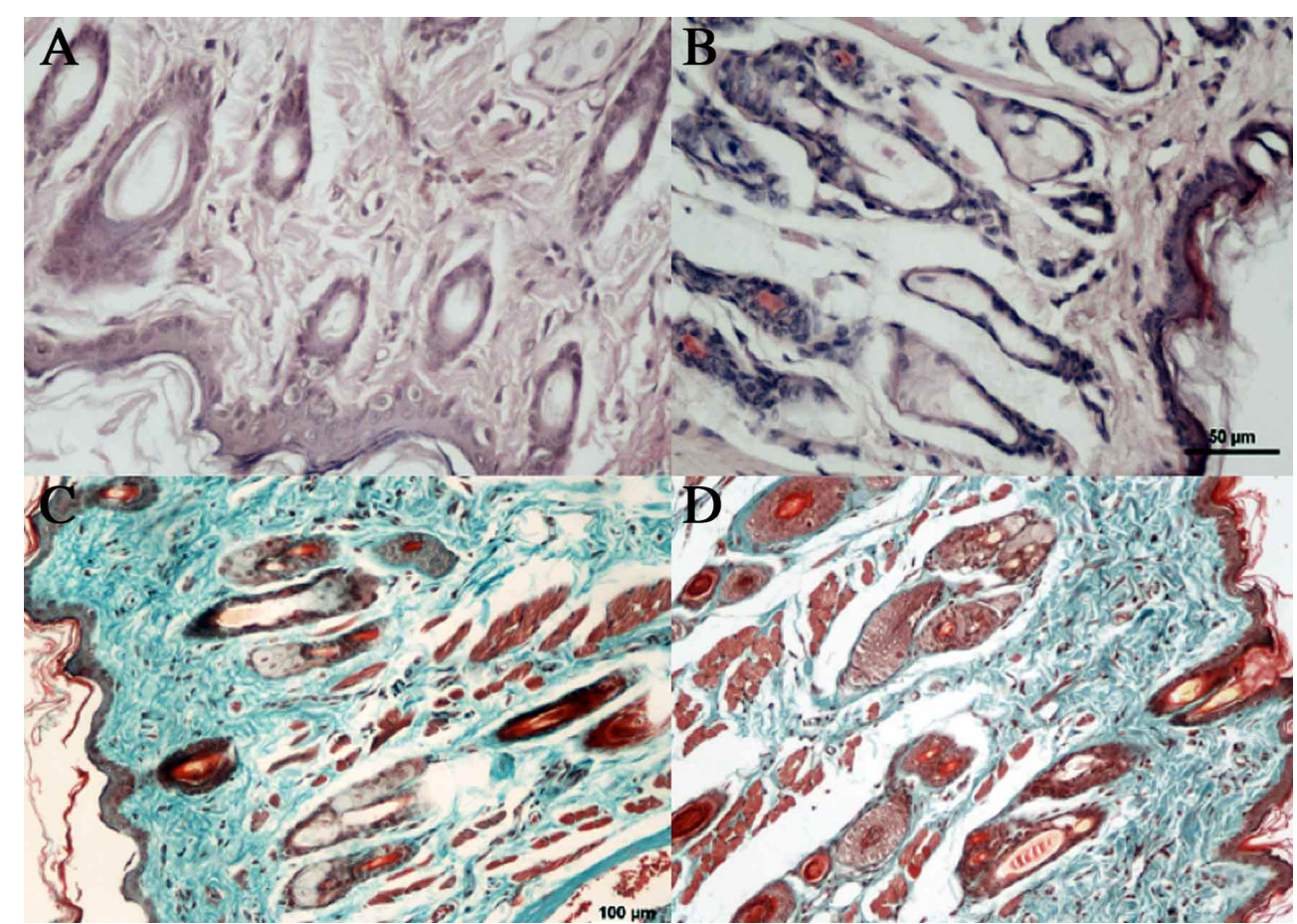

Fig. 1. A. Control group. H-E, Bar $50 \mathrm{~mm}$. B. Thinning of the epidermis and degeneration in dermis. H$\mathrm{E}$, Bar $50 \mathrm{~mm}$. C. An increase keratinization and in collagen fibers. Masson, Bar $100 \mathrm{~mm}$. D. Infiltration of inflammatory cells. Masson, Bar $100 \mu \mathrm{m}$.

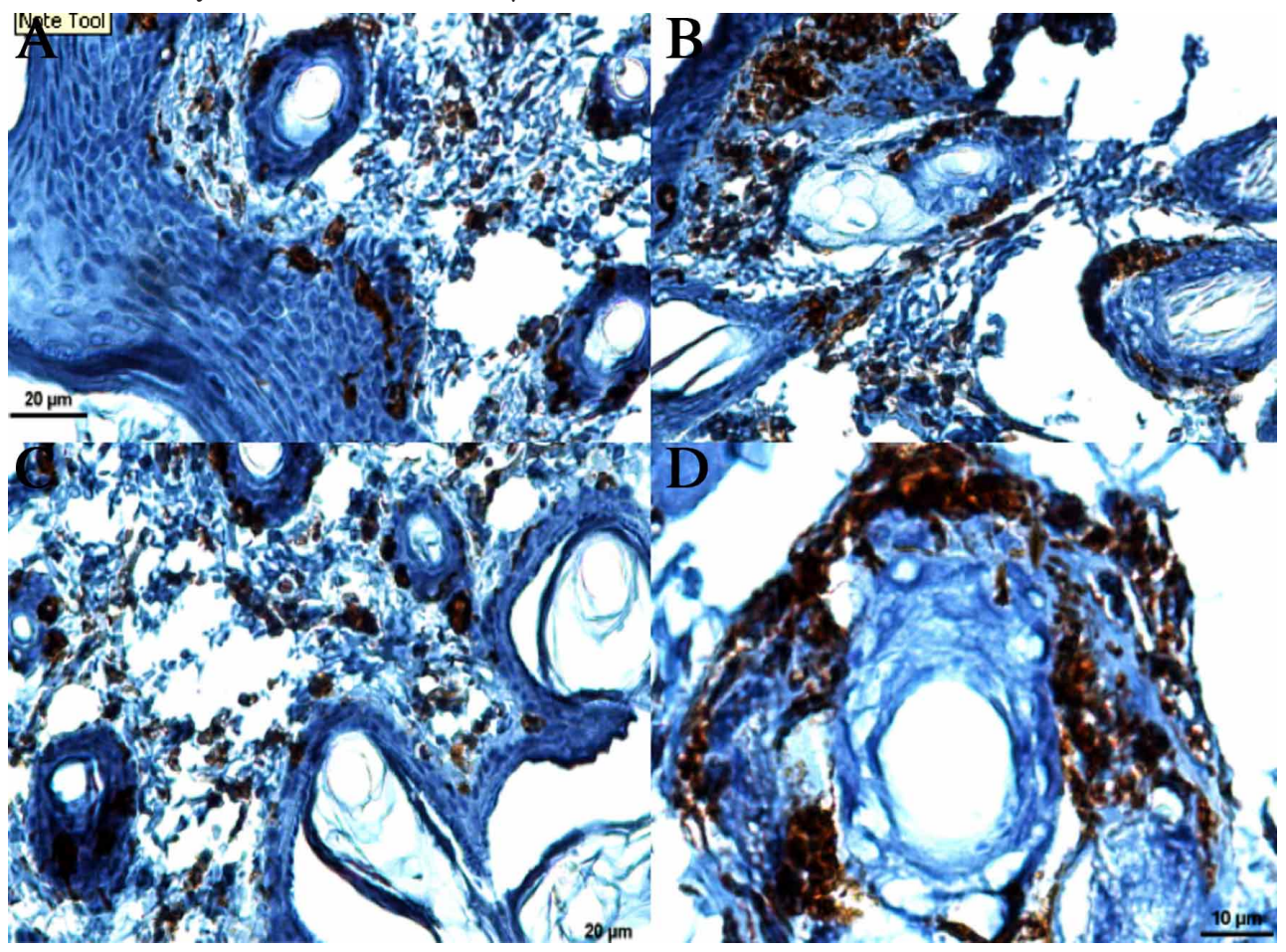

Fig. 2. A. Vimentin positive expression in the dendritic cells. Vimentin-immunoreactivity, Bar 20 mm. B. I'ntense expression of vimentin-positive stromal cells in the dermis. Vimentinimmunoreactivity, Bar $20 \mathrm{~mm}$. C. Myoepitelial vimentin expression in cells surrounding the sebaceous and sweat glands. Vimentin-immunoreactivity, Bar $20 \mathrm{~mm}$. D. Vimentin positive expression in hair folliculli. Vimentin-immunoreactivity, Bar $10 \mathrm{~mm}$. waited outside for 10 minutes. The slides were washed in PBS, and marked the boundaries of tissue on the hydrophobic pen. $3 \%$ hydrogen peroxide were dropped on the tissue and allowed to stand for 15 minutes. Sections were washed in PBS at room temperature and humid 80 min were stained with antibodies to vimentin in the primary. Washed with PBS. Secondary antibodies and streptavidinperoxidase complex, 30 minutes, stained. Diaminobenzidine as the chromogen (DAB) were stained for 3-5 minutes. 1 minute with Harris hematoxylin staining was the opposite.

\section{RESULTS}

Control group and treated group were compared with f o r m a $1 \mathrm{~d} \mathrm{e} \mathrm{h} \mathrm{y} \mathrm{d} \mathrm{e} \mathrm{.}$ Formaldehyde in the group, minimal to slight multifocal hydropic degeneration of basal cell layer, depending on the thinning of the epidermis, the cellular degeneration in the dermis and a decrease in the number of cells was observed in sebaceous glands of the hair follicle hemorrhage. Infiltration of inflammatory cells such as neutrophils, eosinophils, monocytes and hypertrophy of the epidermis were evident, and some mast cell invasion into the dermis was observed in the face-skin (Fig. 1b, c, d) 
There was also increased keratinization of the epidermis in the apical cell degeneration. Formaldehyde group, and some stromal cells in the dermis, tight connective tissue hyperplasia observed increase in collagen fibers.

Vimentin-immunoreactivity was very dense in the dendritic cells of the subepidermal region It was also strongly stained around the myoepithelial cells surrounding sebaceous (Figure 2a, b) and sweat glands. Vimentinimmunoreactivity was observed in the fibroblasts, the smooth muscle of arrectores pilorum muscle, endothelial cells of vessels (Figure 2c, d) and bulbus pilorum of some hair follicles. Vimentin-immunoreactivity was very dense in the smooth muscle cells of vessels, while it was weakly stained in the arrectores pilorum muscles.

\section{DISCUSSION}

The most commonly reported effects include eye, nose, throat, and skin irritation. Other effects include allergic contact dermatitis, histopathological abnormalities (e.g., hyperplasia, squamous metaplasia, and mild dysplasia) of the nasal mucosa, occupational asthma, reduced lung function, altered immune response, and hemotoxicity (IARC, 2006). Some studies of Chinese workers suggest that longterm exposure to formaldehyde can cause leucopenia, and one study reported that a significantly higher percentage of formaldehyde-exposed workers had blood cell abnormalities (leucopenia, thrombocytopenia, and depressed serum hemoglobin levels) compared with unexposed controls (Tang et al.. 2009). Zhang et al. (2010) reported that Chinese factory workers exposed to high levels of formaldehyde had significantly lower counts of white blood cells, granulocytes, platelets, red blood cells and lymphocytes than unexposed controls. The toxic effects of formaldehyde in experimental animals include irritation, cytotoxicity, and cell proliferation in the upper respiratory tract, ocular irritation, pulmonary hyperactivity, bronchoconstriction, gastrointestinal irritation, and skin sensitization. Heid et al., (1988) reported vimentin immunoreactivity in the hair follicle bulbs of mammalian skin. Mesenchymal tissues, especially in the connective tissue of a vimentin intermediate filament protein expressed in the dermal sheath of hair follicles are more. Also supporting the hair follicle is an essential element. vimentinimmunoreactivity was seen in the dermal dentritic cells in which their processes extended into the epidermis.

As a result of histopathological examination, formaldehyde and haemorrhage to cause dilation of the vessel wall caused by the realization of microvascular leakage, inflammatory cell infiltration was observed that changes with a high incidence of acute inflammation. formaldehyde in rats, inflammation of the dermis cells, fibroblasts, and sebaceous glands in the hair follicle damage is apparent, depending on the expression of vimentin filament proteins is due to be considered.

KALKANLI, S.; KALKANLI, N.; DEVECI, E.; DAL, T. \& BARAN, O. Efectos de formaldehído y expresión de vimentina en la piel de rata. Int. J. Morphol., 31(3):845-848, 2013.

RESUMEN: En este ensayo se utilizaron ratas Wistar (9 semanas de edad, 180-200 g de peso corporal) que se dividieron en dos grupos de 16 animales cada uno (grupos control y experimental). Los animales del grupo experimental fueron colocados en un vaso de vidrio de tamaño 100x65x100. Durante un período de tiempo de 8 semanas, 5 días a la semana con 8 horas se expuso a la inhalación de $10 \mathrm{ppm}$ de formaldehído. Se retiró la piel y se colocó en formalina al 10\%. Las secciones fueron teñidas con Hematoxilina-Eosina y Tricrómico de Masson, y fueron observadas al microscopio óptico. Las técnicas histopatológicas e inmunohistoquímicas y el impacto en la piel provocado por el formaldehído permitieron examinar la expresión de vimentina.

PALABRAS CLAVE: Formaldehído; Piel; Vimentina.

\section{REFERENCES}

Bavdek, S. V.; Golob, Z.; van Dijk, J.; Dorrestein, G. M. \& Fazarinc, G. Vimentin- and desmin-positive cells in the moulting budgerigar (Melopsittacus undulatus) skin. Anat. Histol. Embryol., 26(3):173-8, 1997.

Golalipour, M. J.; Azarhoush, R.; Ghafari, S.; Gharravi, A. M.; Fazeli, S. A. \& Davarian, A. Formaldehyde exposure induces histopathological and morphometric changes in the rat testis. Folia Morphol. (Warsz), 66(3):167-71, 2007.
Heid, H. W.; Moll, I. \& Franke, W. W. Patterns of expression of trichocytic and epithelial cytokeratins in mammalian tissues. I. Human and bovine hair follicles. Differentiation, 37(2):13757,1988 .

IARC, Working Group on the Evaluation of Carcinogenic Risks to Humans. Formaldehyde, 2-butoxyethanol and 1-tertbutoxypropan-2-ol. IARC Monogr. Eval. Carcinog. Risks Hum., 88:1-478, 2006. 
Kacem, K.; Seylaz, J. \& Aubineau, P. Differential processes of vascular smooth muscle cell differentiation within elastic and muscular arteries of rats and rabbits: an immunofluorescence study of desmin and vimentin distribution. Histochem. J., 28(1):53-61, 1996.

Lazarides, E. Intermediate filaments as mechanical integrators of cellular space. Nature, 283(5744):249-256, 1980.

Mathur, N. \& Rastogi, S. K. Respiratory effects due to occupational exposure to formaldehyde: Systematic review with metaanalysis. Indian J. Occup. Environ. Med., 11(1):26-31, 2007.

Rode, B.; Bavdek, S. V.; Lackovic, G.; Fazarinc, G. \& Bidovec, A. Immunohistochemical study of normal and mange (S. scabiei var. rupicaprae) infested chamois (Rupicapra rupicapra L.) skin. Anat. Histol. Embryol., 27(3):187-92, 1998.

Tang, X.; Bai, Y.; Duong, A.; Smith, M. T.; Li, L. \& Zhang, L. Formaldehyde in China: production, consumption, exposure levels, and health effects. Environ. Int., 35(8):1210-24, 2009.

Zhang, L.; Tang, X.; Rothman, N.; Vermeulen, R.; Ji, Z.; Shen M.; et al. Occupational exposure to formaldehyde, hematotoxicity, and leukemia-specific chromosome changes in cultured myeloid progenitor cells. Cancer Epidemiol. Biomarkers Prev., 19(1):80-8, 2010.
Correspondence to:

Engin Deveci

Dicle University

Medical Faculty

Histology and Embryology Dept.

21280 Diyarbakır

TURKEY

Email: engindeveci64@gmail.com

Received: 10-12-2012

Accepted: 01-05-2013 